University of Nebraska - Lincoln

DigitalCommons@University of Nebraska - Lincoln

Faculty Publications from the Harold W. Manter Laboratory of Parasitology

2005

\title{
Redescription and New Host Record of Eimeria serbica from the Caucasian Tree Squirrel, Sciurus anomalus, from Turkey
}

Lee Couch

University of New Mexico, Icouch@unm.edu

Atilla Arslan

Selcuk University, aarslan@selcuk.edu.tr

Donald W. Duszynski

University of New Mexico, eimeria@unm.edu

Follow this and additional works at: https://digitalcommons.unl.edu/parasitologyfacpubs

Part of the Parasitology Commons

Couch, Lee; Arslan, Atilla; and Duszynski, Donald W., "Redescription and New Host Record of Eimeria serbica from the Caucasian Tree Squirrel, Sciurus anomalus, from Turkey" (2005). Faculty Publications from the Harold W. Manter Laboratory of Parasitology. 136.

https://digitalcommons.unl.edu/parasitologyfacpubs/136

This Article is brought to you for free and open access by the Parasitology, Harold W. Manter Laboratory of at DigitalCommons@University of Nebraska - Lincoln. It has been accepted for inclusion in Faculty Publications from the Harold W. Manter Laboratory of Parasitology by an authorized administrator of DigitalCommons@University of Nebraska - Lincoln. 


\title{
REDESCRIPTION AND NEW HOST RECORD OF EIMERIA SERBICA FROM THE CAUCASIAN TREE SQUIRREL, SCIURUS ANOMALUS, FROM TURKEY
}

\author{
Lee Couch, Atilla Arslan*, and Donald W. Duszynski \\ Department of Biology, The University of New Mexico, Albuquerque, New Mexico 87131. e-mail: Icouch@unm.edu
}

\begin{abstract}
Fecal samples from 20 Caucasian tree squirrels, Sciurus anomalus (Gmelin, 1778) Güldenstaedt, 1785, were collected in Turkey during February and March, 2004, and all 20 were infected with a single species of coccidia, Eimeria serbica. Sporulated oocysts are ellipsoidal, $27.5 \times 17.5(21-34 \times 15-20)$ with a length:width ratio (L/W) of 1.6 (1.4-1.8); they lack a micropyle and oocyst residuum, but 0-2 polar granules may be present. Sporocysts are ellipsoidal, $11.9 \times 6.9(10.5-14 \times 6-$ 7.5) with a L/W of 1.7 (1.5-2.1); a Stieda body and sporocyst residuum are present.
\end{abstract}

The order Rodentia has more described species than any other mammalian order. In one family alone, the Sciuridae, there are 50 genera with 260 species that are found in a wide variety of habitats throughout most of the New World and Eurasia (Walker, 1991; Wilson and Reeder, 1993). To date, $>450$ species of coccidia have been described from various rodent genera (Duszynski and Upton, 2001), but none has been described from the Caucasian tree squirrel Sciurus anomalus. Here, we report new host and geographic records for Eimeria serbica Pop-Cenitch \& Bordjochki, 1957, thus adding to our continually growing knowledge of the parasite fauna of rodents.

\section{MATERIALS AND METHODS}

Between February and March, 2004, 20 fecal samples were collected from Caucasian tree squirrels in Turkey; 16 were live-trapped and feces collected upon defecation. The other 4 were killed and feces collected directly from their intestines. Fecal material was placed in vials of $2 \%$ $(\mathrm{w} / \mathrm{v})$ aqueous potassium dichromate $\left(\mathrm{K}_{2} \mathrm{Cr}_{2} \mathrm{O}_{7}\right)$ solution, mixed thoroughly, and temporarily refrigerated at $4 \mathrm{C}$ before being shipped to the United States. Upon receipt at the University of New Mexico, the samples were stored at ambient temperature for $\sim 2-3$ mo until they could be processed and screened for coccidia as detailed by Duszynski and Wilber (1997). Oocysts were measured and photographed using both bright-field and Nomarski differential interference contrast (DIC) microscopy. Because only line drawings of the oocysts have been published (Pop-Cenitch and Bordjochki, 1957; Ryšavý and Eerná, 1979), we have included photomicrographs with this manuscript and submitted 2 photosyntypes to the U.S. National Parasite Collection in Beltsville, Maryland. Standardized abbreviations for oocyst and sporocyst structures generally follow those of Wilber et al. (1998): oocyst characters: length (L) and width (W) with their ranges, and ratios (L/W), micropyle (M), residuum (OR), polar granules (PG); sporocyst characters: L, W, ranges, and L/W, Stieda body (SB), substieda body (SSB), parastieda body (PSB), residuum (SR), sporozoites (SZ), refractile bodies (RB), and nucleus $(\mathrm{N})$ in SZ. All measurements are in micrometers $(\mu \mathrm{m})$ with ranges in parentheses after the means.

\section{DESCRIPTION}

\section{Eimeria serbica Pop-Cenitch \& Bordjochki, 1957 (Figs. 1-2)}

Description of sporulated oocyst: Oocyst shape: ellipsoidal; number of walls: 1 ; wall thickness: 1.5 ; wall characteristics: smooth; $\mathrm{L} \times \mathrm{W}(\mathrm{n}$ $=50)$ : 27.5 by 17.5 (21-34 by $15-20)$; L/W: $1.6(1.4-1.8)$; M: absent; OR: absent; PGs: 0-2. Distinctive features of oocyst: ellipsoidal shape with smooth, thick outer wall.

Description of sporocyst and sporozoites: Sporocyst shape: ellipsoidal; L $\times$ W: 11.9 by 6.9 (10.5-14 by 6-7.5); L/W: 1.7 (1.5-2.1); SB: present; SSB: absent; PSB: absent; SR: present; SR characteristics:

Received 4 January 2005; revised 22 March 2005; accepted 23 March 2005.

* Selcuk University, Science and Art Faculty, Department of Biology, Campus 42031 Konya, Turkey.

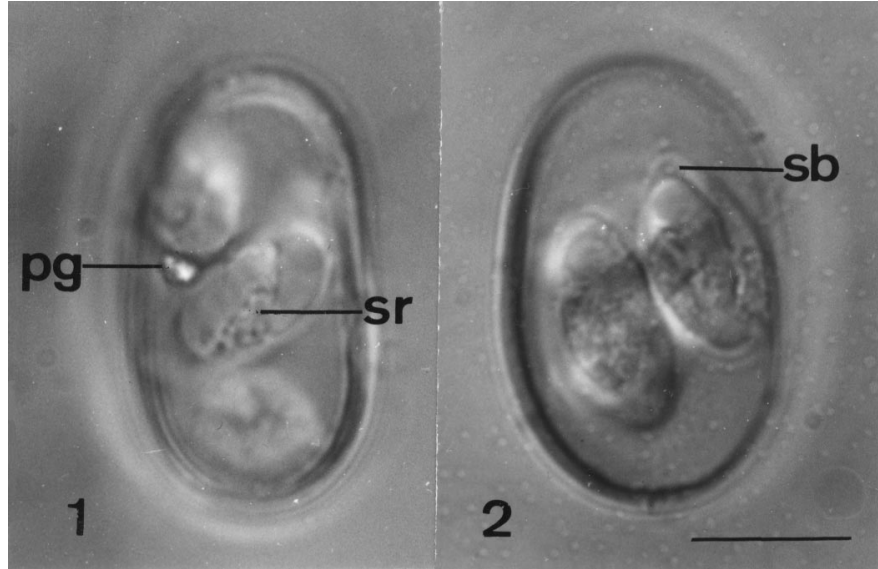

FIGURES 1-2. Photomicrographs of sporulated oocysts of Eimeria serbica Pop-Cenitch and Bordjochki, 1957 from Sciurus anomalus from Turkey. Scale bar $=10 \mu \mathrm{m}$. Note the ellipsoidal shape, distinct polar granule, and presence of a Stieda body and sporocyst residuum. Abbreviations: pg, polar granule; sb, Stieda body; sr, sporocyst residuum.

small to medium-sized granules dispersed between SZ; SP: lie head to tail, with 1 distinct posterior RB; $\mathrm{N}$ not visible.

\section{Taxonomic summary}

Type host: Presumably Sciurus vulgaris Linnaeus, 1758, Eurasian red squirrel, but this was not stated in the original description.

Other hosts (this study): Sciurus anomalus (Gmelin, 1778) Güldenstaedt, 1785, Caucasian tree squirrel.

Type locality: EUROPE: Yugoslavia: Serbia, Belgrade Zoo.

Geographic distribution: EUROPE: Yugoslavia, Czech Republic; ASIA: Turkey: Aydin, Elazi ̌̆, Konya.

Prevalence: 20/20 (100\%) S. anomalus (this study); 1/4 (25\%) $S$ vulgaris in Yugoslavia (Pop-Cenitch and Bordjochki, 1957); 4/4 (?)

TABLE I. Caucasian tree squirrels (Sciurus anomalus) collected from 5 localities in Turkey and examined for coccidia. All were infected with a single species of Eimeria (E. serbica).

\begin{tabular}{lcl}
\hline \multicolumn{1}{c}{ Squirrel no. } & Date collected & \multicolumn{1}{c}{ Locality } \\
\hline $1,2,3,4$ (all killed) & 14 February 2004 & $\begin{array}{l}\text { Bozkir, Kenya } \\
\text { Karasalkim Village, Palu, } \\
\text { Elaziğ } \\
\text { Kayadibi Village, Hatun- } \\
\text { Saray, Konya }\end{array}$ \\
$8,9,10,11,12$ & 25 February 2004 & $\begin{array}{c}\text { Kizilca Village, Köşk, } \\
\text { Aydin } \\
13,14,15,16\end{array}$ \\
$17,18,19,20$ & 28 February 2004 & $\begin{array}{c}\text { Fakilar Village, Hadim, } \\
\text { Konya }\end{array}$ \\
\hline
\end{tabular}


(100\%) S. vulgaris in the Czech Republic (Jírovec, 1942; Ryšavý, 1954; Ryšavý and Cerná, 1979).

Sporulation: At least 12 days at $25 \mathrm{C}$ (Pop-Cenitch and Bordjochki, 1957) or 96 hr at 16-18 C. (Ryšavý and Černá, 1979).

Prepatent and patent periods: Unknown.

Site of infection: "Intestine," see Jírovec (1942) and Ryšavý and Cerná (1979).

Material deposited: Photosyntypes of sporulated oocysts deposited in the U.S. National Parasite Collection (USNPC), Beltsville, Maryland, No. 95336

\section{Remarks}

Ryšavý and Černá (1979) speculated that this species was first described in the Czech Republic by Jírovec (1942) who misidentified it as Eimeria sciurorum Galli-Valerio, 1922; however, the form described by Jírovec (1942) had oocysts that were $30-50$ by $15-35$, much too large to be E. serbica. Ryšavý (1954) "described evidently the same species from the same host [species]," but also called it E. sciurorum (Ryšavý and Černá, 1979). Three years later, Pop-Cenitch and Bordjochki (1957) described and named E. serbica from $S$. vulgaris in Yugoslovia. Sporulated oocysts of E. serbica that we measured from $S$. anomalus are almost identical in shape (ellipsoidal) and size (21-34 by 15-20, mean 27.5 by 17.5) to those first described from the Eurasian red squirrel $S$. vulgaris from Yugoslavia (21-35 by 12-24, in Pop-Cenitch and Bordjochki, 1957). Additionally, sporocyst size and characteristics from the original description of E. serbica (7-8 by $12-13$; SB and SR of "conspicuous dense dark small granules") were similar to the sporocysts we found in $S$. anomalus (6-7.5 by $10.5-14$, mean 6.9 by 11.9). This is the first record of an eimerian infecting the Caucasian tree squirrel.

\section{DISCUSSION}

Sciurus vulgaris (subgenus Sciurus L., 1758) is found throughout Europe and northern Asia, whereas S. anomalus (subgenus Tenes Thomas, 1909) is geographically isolated as the only sciurid species in areas of Caucasus, Asia Minor, Syria, Palestine, and western Iran (Walker, 1991). Thus, the 2 species of squirrels are not known to overlap in their geographical lo- calities, and the fact that they both harbor the same species of eimeriid coccidia is interesting, but perplexing. However, it is not uncommon for eimerians that infect 1 species of rodent to be able to infect another congeneric species (e.g., Hnida and Duszynski, 1999). Thus, it seemed the prudent choice at this time to assume that the form we saw in S. anomalus was actually $E$. serbica, rather than to create a new species for a form discharging such similar oocysts.

\section{LITERATURE CITED}

Duszynski, D. W., AND P. G. WiLber. 1997. A guideline for the preparation of species descriptions in the Eimeriidae. Journal of Parasitology 83: 333-336.

, AND S. J. UPTON. 2001. Enteric protozoa: Cyclospora, Eimeria, Isospora and Cryptosporidium. In Parasitic diseases of wild mammals, 2nd ed., W. M. Samuel, M. J. Pybus, and A. A. Kocan (eds.). Iowa State University Press, Ames, Iowa, p. 416-459.

HNIDA, J. A., AND D. W. DuszYNSKI. 1999. Cross-transmission studies with Eimeria arizonensis, E. arizonensis-like oocysts and Eimeria langebarteli: Host specificity at the genus and species level within the Muridae. Journal of Parasitology 85: 873-877.

JiRovec, O. 1942. Three rare coccidia from our vertebrates. Příroda 35: 72-73. [In Czech.]

Pop-Cenitch, S., AND A. BordjochKi. 1957. Sur une nouvelle espèce de coccidia de l'écureuil. Archives de 1'Institut Pasteur d'Algerie 35: 73-75.

RYŠAvÝ, B. 1954. Přispěvek k poznáni kokeidií năsich I dorezených obretloveů. Czechoslovak Parasitology 1: 131-174.

, AND Z. CERnÁ. 1979. Coccidian parasites (Coccidia, Eimeriidae) of the squirrel Sciurus vulgaris L. from Czechoslovakia. Folia Parasitologica (Praha) 25: 65-68.

Walker, R. M. 1991. Walker's mammals of the world, Vol. 1. The Johns Hopkins University Press, Baltimore, Maryland, 642 p.

Wilber, P. G., D. W. Duszynski, S. J. Upton, R. S. Seville, and J. O. CORLISS. 1998. A revision of the taxonomy and nomenclature of the Eimeria spp. (Apicomplexa: Eimeriidae) from rodents in the Tribe Marmotini (Sciuridae). Systematic Parasitology 39: 113-135.

Wilson, D. E., AND D. M. REEDER. 1993. Mammal species of the world. Smithsonian Institution Press, Washington, D.C., 1,206 p. 